\title{
Real-Time Wireless Concept of Vehicle to Vehicle Charging System
}

\author{
Yurni Oktarina ${ }^{1}$ Tresna Dewi ${ }^{1, *}$ Pola Risma ${ }^{1}$ Muhammad Nawawi ${ }^{1}$
}

\author{
${ }^{1}$ Electrical Engineering Department, Politeknik Negeri Sriwijaya, Jalan Srijaya Negara Palembang, Indonesia 30139 \\ ${ }^{*}$ Corresponding author. Email: tresna_dewi@polsri.ac.id
}

\begin{abstract}
The electric vehicle is the automotive future that supports the program of utilizing renewable energy over depleting fossil fuel. The electric vehicle enables us to have a better environment free of $\mathrm{CO} 2$ emission. The issue of electric vehicle applications is charging points, not as many as the conventional charging station. This study investigates the concept of the real-time wireless vehicle to the vehicle charging system. The concept is realized by simulating it with two line-follower robots acting as the vehicles move side by side, where vehicle 1 charges vehicle 2 . The maximum transferred voltage is 5.20 volt, and the maximum current is $93.50 \mathrm{~mA}$ with a closed distance of $1 \mathrm{~cm}$. This maximum transferred energy results in the fastest velocity of 210 RPM. The highest distance possible between these two robots are $3.5 \mathrm{~cm}$, and the induction is more potent as the distance is shorter. This concept enables charging without the vehicle in a stationary position.
\end{abstract}

Keywords: Receiver, transmitter, vehicle to vehicle, wireless energy transfer

\section{INTRODUCTION}

The electric vehicle is the automotive future where the power comes from generated electricity rather than utilizing the depleting fossil fuel [1]-[14]. The electric vehicle has stormed the world with its advantages over a conventional vehicle. This technology's application is more environmentally friendly than fossil fuel consumption that leads to the greenhouse effect. This alternative technology is growing fast and becomes the modern transportation system [15][16]. The electric vehicle can be developed more to be an autonomous vehicle.

The electric vehicle comes as the product of various technology, including mechanical, chemical, electrical, electronics, and automotive engineering. These different technologies are utilized to create an electric vehicle and realize an effective and efficient vehicle for power/fuel consumption. The electric vehicle consists of an electric motor to drive and utilize the electrical energy deposited in batteries, a power converter to convert the electrical energy into mechanical energy, and energy source management. The electric vehicle designs include identifying the applied environment and determining the technical specifications, including estimating loads, considering the energy source, which is batteries, motors, and its parameters.
One of the electric vehicle's issues is the energy management system, including charging and discharging electric vehicle. The emerging technology is including vehicle to grid, smart grid, and vehicle to vehicle charging $(\mathrm{V} 2 \mathrm{~V})$. V2V can be very useful since the charging can occur anywhere without having to come to the specific charging station concerning; currently, the charging stations of electric vehicles are not as many as the conventional fossil fuel charging stations (gas stations).

The V2V system can be developed more by adopting the wireless charging system, where the source vehicle charged the other vehicle without connected by a physical wire [17]-[40]. This wireless charging system is more promising and effective since it is not required to stop or be stationary. This paper discusses the concept of real-time wireless charging of vehicle-tovehicle charging system. The wireless system allows the vehicle to keep moving, such as a bus or an automatic vehicle; therefore, this system does not interfere with an automatic vehicle's schedule system. The vehicle to vehicle charging in this study is simulated by using two mobile robots demonstrating the automatic vehicle. This study is the continuation of our studies published in [16]-[19], which are the fundamental of the wireless system, and [16] discusses the concept of the automatic vehicle. 


\section{METHODS}

This study discusses the concept of V2V charging by adopting the wireless technology applied to two linefollower robots as simulating devices. The experimental test-bed is set by installing the transmitter devices on vehicle one as the charging device, and receiver coil to vehicle 2 . Vehicle one moves side by side with vehicle 2 , charging online and in real-time.

\subsection{Wireless Energy Concept}

Wireless energy is not a new thing in electricity transmitting and charging. First introduced by Nikola Tesla in 1890 and was able to power a lamp without any contacting physical devices. The most applied wireless energy transfer (WET) in the near field method using magnetic coupling coils. The mid-air gap between transmitter and receiver functions as the media to transfer the power from transmitter to receiver. This method, however, is highly affected by the distance of the transmitter and receiver. The early concept of WET used the AC voltage source with a constant amplitude. In this study, the source is changed into a DC voltage source to imitate the energy transfer from a battery in a vehicle to the battery at the other vehicle (the charged vehicle).

The magnetic coupling method applied in this study is given in Figure 1, where the circuit is divided into the transmitter $(\mathrm{T})$ and receiver $(\mathrm{R})$. Therefore, $i_{T}, L_{T}, R_{T}$, and $C_{T}$ are current, inductor, resistance, and capacitor at the transmitter side, while $i_{R}, L_{R}, R_{R}$, and $C_{R}$ are current, inductor, resistance, and capacitor at the receiver side. The load is positioned in the $R_{L}$, which is in this study in vehicle 2 . The distance between transmitter and receiver is $d$, and $M$ is the magnetic induction between them.

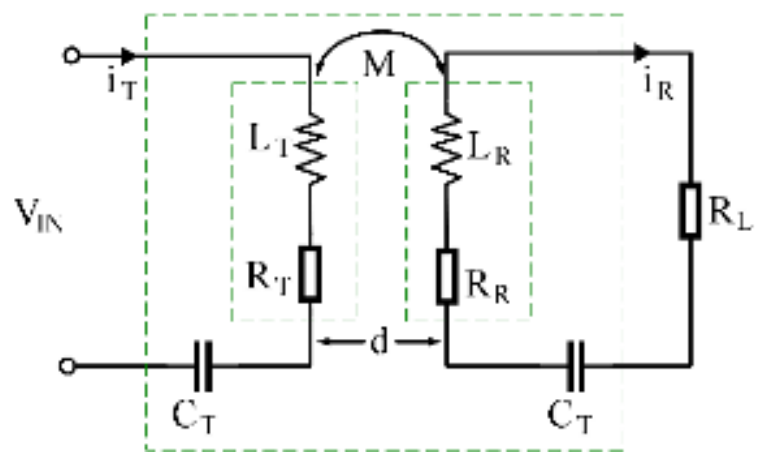

Figure 1 The model of the wireless energy concept adopted in this study.

The impedance presentation of magnetic induction in Figure 1 is given by
Figure 1 shows the energy coupling between the transmitter and receiver due to the inductor interception of a magnetic field produced by the transmitter. The coupling coefficient is calculated by

and

$$
V_{T}=j \omega L_{T} i_{T}+j \omega M i_{R}
$$

$$
V_{R}=j \omega M i_{T}+j \omega L_{R} i_{R} .
$$

Figure 1 shows the energy coupling between the transmitter and receiver due to the inductor interception of a magnetic field produced by the transmitter. The coupling coefficient is calculated by

$$
k=\frac{M}{\sqrt{L_{T} L_{R}}} \text {. }
$$

The power coupling in the transmitter side is the product of magnetic induction $(\mathrm{M})$ and the receiver current $\left(i_{R}\right)$, and the power coupling on the receiver side occurs due to transmitter current $\left(i_{T}\right)$ flowing in the transmitter, which is coupled by the mutual induction.

The magnetic induction in Figure 1 is positively affected by the distance between transmitter and receiver and given by

$$
M=\frac{\mu_{0} i R}{2 \pi d} .
$$

where $\mu_{0}$ is $4 \pi \times 10^{-7} \mathrm{WbA}$, magnetic flux ( $\left.\Phi\right)$ is given $\Phi$ is the product of magnetic induction and coil's crosssectional area, and the produced electrical power $(\mathrm{P})$ is the product of voltage and current in the receiver.

\subsection{Wireless Vehicle to Vehicle Charging}

The wireless V2V charging concept adopts the possibility of using WET to charge the nearby electric vehicle. The advantage of wireless $\mathrm{V} 2 \mathrm{~V}$ is charging, and the charged vehicle does not need to stop. They can be driving side by side. This method is effective and applicable for an autonomous vehicle with a particular schedule.

The possibility of applying the wireless V2V concept is shown in the block diagram in Figure 2. Vehicle 1, having the transmitter coil, becomes the charging point for vehicle 2 . The concept is that vehicle 1 emits the magnetic coupling to transfer the electricity to vehicle 2 . The experimental design shows that vehicle 1 carries the transmitter coil, and vehicle 2 gets the receiver coil, as shown in Figure 3. The experimental setup and testbed are given in Figure 4. This setup is to prove the possibility of applying the wireless $\mathrm{V} 2 \mathrm{~V}$ concept. 


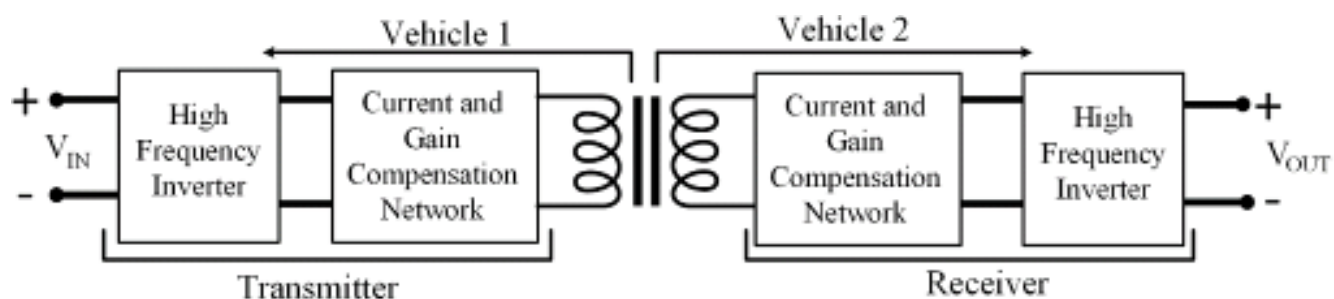

Figure 2 The wireless V2V charging concept2. The wireless V2V charging concept.
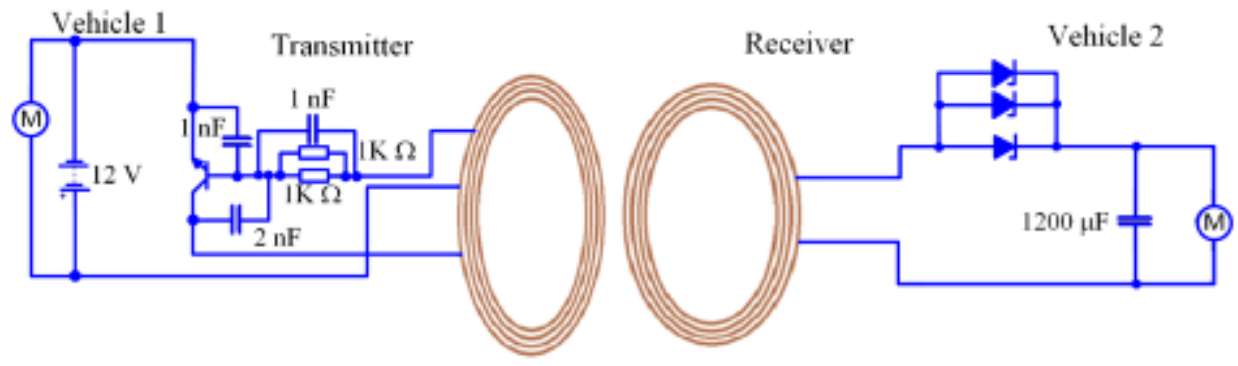

Figure 3 The electric circuit of both transmitter and receiver is installed on the experimental test-bed.

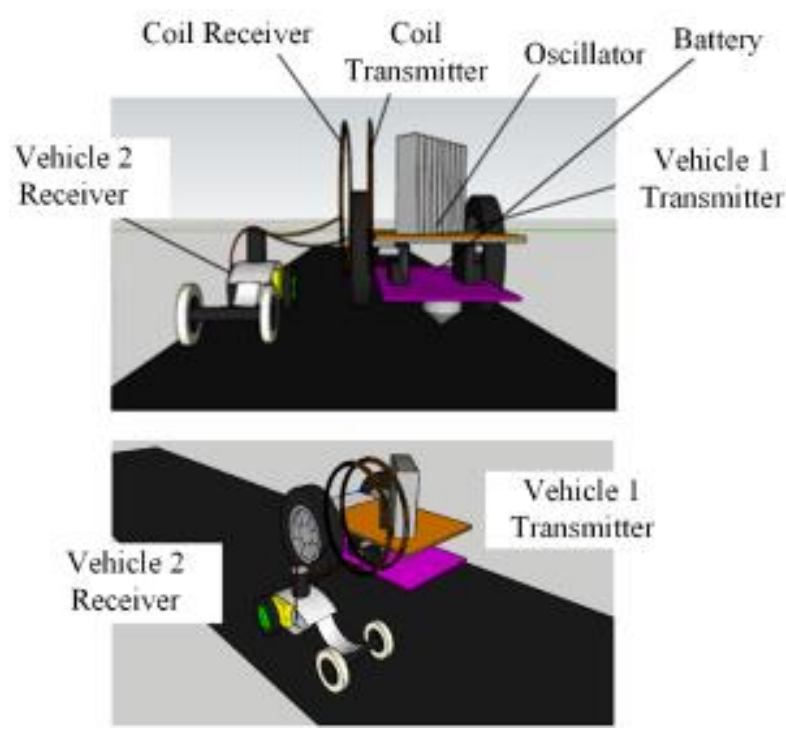

Figure 4 The transmitter and receiver vehicles considered in this study.

\section{RESULT AND DISCUSSION}

The wireless $\mathrm{V} 2 \mathrm{~V}$ charging concept is realized in Figure 5, where two line-follower robots act as the vehicles move side by side, where vehicle one charges vehicle 2. Wireless power transmission works by utilizing the principle of electromagnetic resonance, which is that two copper coils resonate with the same frequency between the transmitter and receiver. The transmitter coil is connected to the battery, which moves the line follower robot as vehicle 1 to charge another line follower robot as vehicle 2. The electrical energy that comes from the battery makes the copper coil resonate at a particular frequency.

Furthermore, the space around the copper coil is filled with non-magnetic radiation. This condition creates a magnetic field that will transmit energy to the copper coil, so the coil connected to the receiver can resonate in the same frequency as the first copper coil (transmitter). So, the line follower robot at the transmitter and receiver parts can go hand in hand.

The complete experimental results of the wireless $\mathrm{V} 2 \mathrm{~V}$ charging concept are shown in Table 1, where dist is distance, $\mathrm{V}$ is voltage, $\mathrm{P}$ is power, and velocity is both vehicle 1 and 2 velocity. It is shown that the velocity of the robots is affected by the power transferred between robots. Figure 6 shows the transferred power and the velocity of the robots. Since the robots are moving simultaneously; therefore, the velocities are the same. Figure 7 shows the relationship between produce powered, the distance of $\mathrm{Tx}$ and $\mathrm{Rx}$, and magnetic induction. Table 2 shows the magnetic induction (B), flux $(\Phi)$, and frequency (f) achieved by calculation. 


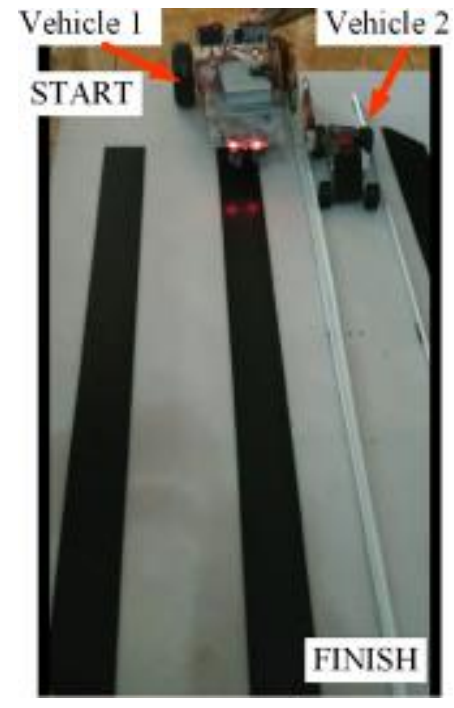

(a)

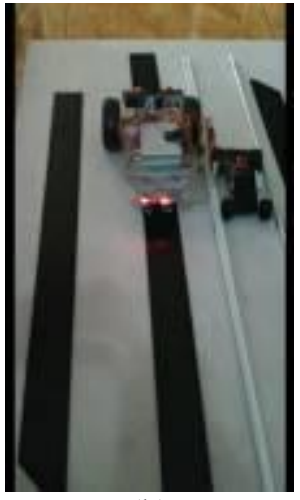

(b)

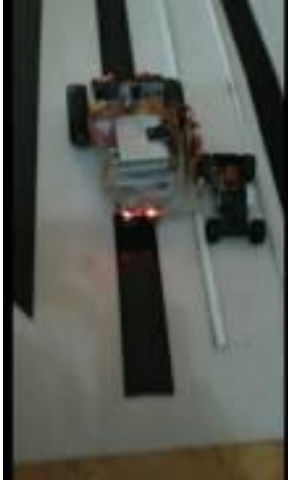

(c)

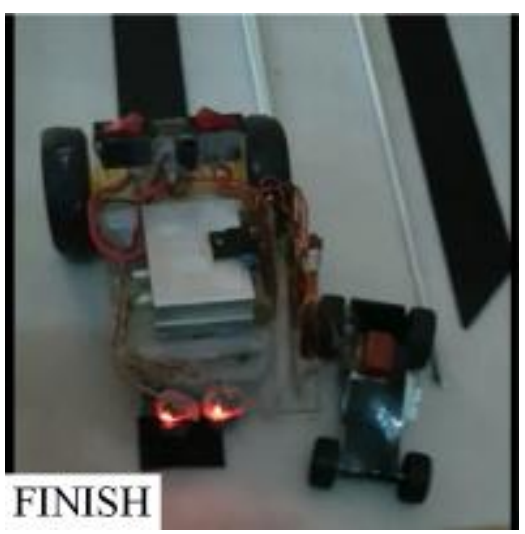

(d)

Figure 5 The experiment of wireless V2V concept

Tabel 1. The experimental result of the transferred power and velocity

\begin{tabular}{ccccc}
\hline $\begin{array}{c}\text { Dist } \\
\text { (cm) }\end{array}$ & $\begin{array}{c}\mathbf{V} \\
(\mathbf{V})\end{array}$ & $\begin{array}{c}\mathbf{I} \\
(\mathbf{m A})\end{array}$ & $\begin{array}{c}\mathbf{P} \\
\text { (Watt) }\end{array}$ & $\begin{array}{c}\text { Velocity } \\
\text { (RPM) }\end{array}$ \\
\hline \multirow{4}{*}{1} & 5.20 & 93.50 & 0.48 & 210.00 \\
& 5.20 & 94.00 & 0.48 & 189.90 \\
& 5.10 & 94.00 & 0.47 & 188.50 \\
\hline \multirow{4}{*}{1.5} & 4.30 & 73.70 & 0.31 & 179.50 \\
& 4.30 & 73.90 & 0.31 & 175.70 \\
& 4.20 & 73.20 & 0.30 & 175.60 \\
\hline \multirow{3}{*}{2} & 3.20 & 61.70 & 0.19 & 130.40 \\
& 3.50 & 61.10 & 0.21 & 133.80 \\
& 3.40 & 61.90 & 0.21 & 133.00 \\
\hline \multirow{3}{*}{2.5} & 2.50 & 50.50 & 0.12 & 72.00 \\
& 2.60 & 50.40 & 0.13 & 78.30 \\
& 2.50 & 51.20 & 0.12 & 74.50 \\
\hline \multirow{3}{*}{3} & 1.80 & 41.40 & 0.07 & 63.70 \\
& 2.10 & 41.80 & 0.08 & 61.60 \\
& 2.00 & 41.50 & 0.08 & 64.00 \\
\hline \multirow{3}{*}{3.5} & 1.30 & 32.80 & 0.04 & 37.20 \\
& 1.40 & 32.70 & 0.04 & 41.40 \\
& 1.50 & 32.20 & 0.04 & 37.00 \\
\hline
\end{tabular}

Figure 6 The transferred power VS the vehicle velocity.

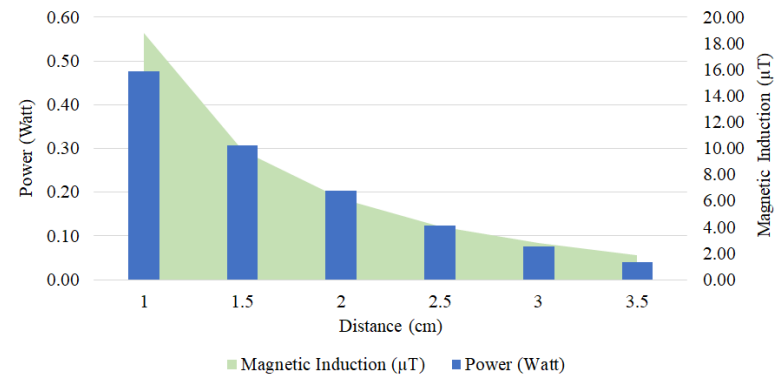

Figure 7 The relationship among produce powered, the distance of Tx and Rx, and magnetic induction. 
The maximum transferred voltage is 5.20 volt, and the maximum current is $93.50 \mathrm{~mA}$ with a closed distance of $1 \mathrm{~cm}$. This maximum transferred energy results in the fastest velocity of 210 RPM. The wireless $\mathrm{V} 2 \mathrm{~V}$ charging concept promises the advantages of charging without physical media and without the vehicles' necessity to be in a stationary position. This concept is realized by simulating it with two linefollower robots. This proposed method is effective at a certain point.

Tabel 2 The magnetic induction, flux, and frequency.

\begin{tabular}{|c|c|c|c|}
\hline $\begin{array}{l}\text { Dist } \\
\text { (cm) }\end{array}$ & $B(T)$ & $\Phi(\mathbf{W b})$ & $\mathbf{f}(\mathrm{Hz})$ \\
\hline \multirow{3}{*}{1} & $18.7 \times 10^{-7}$ & $14.02 \times 10^{-9}$ & 10.45 \\
\hline & $18.8 \times 10^{-7}$ & $14.10 \times 10^{-9}$ & 9.49 \\
\hline & $18.8 \times 10^{-7}$ & $14.10 \times 10^{-9}$ & 9.42 \\
\hline \multirow{3}{*}{1.5} & $9.82 \times 10^{-7}$ & $7.36 \times 10^{-9}$ & 8.97 \\
\hline & $9.85 \times 10^{-7}$ & $7.38 \times 10^{-9}$ & 8.78 \\
\hline & $9.76 \times 10^{-7}$ & $7.32 \times 10^{-9}$ & 8.78 \\
\hline \multirow{3}{*}{2} & $6.17 \times 10^{-7}$ & $4.62 \times 10^{-9}$ & 6.52 \\
\hline & $6.11 \times 10^{-7}$ & $4.58 \times 10^{-9}$ & 6.69 \\
\hline & $6.19 \times 10^{-7}$ & $4.64 \times 10^{-9}$ & 6.65 \\
\hline \multirow{3}{*}{2.5} & $4.04 \times 10^{-7}$ & $3.03 \times 10^{-9}$ & 3.6 \\
\hline & $4.03 \times 10^{-7}$ & $3.02 \times 10^{-9}$ & 3.91 \\
\hline & $4.09 \times 10^{-7}$ & $3.06 \times 10^{-9}$ & 3.72 \\
\hline \multirow{3}{*}{3} & $2.76 \times 10^{-7}$ & $2.07 \times 10^{-9}$ & 3.18 \\
\hline & $2.78 \times 10^{-7}$ & $2.08 \times 10^{-9}$ & 3.08 \\
\hline & $2.76 \times 10^{-7}$ & $2.07 \times 10^{-9}$ & 3.2 \\
\hline \multirow{3}{*}{3.5} & $1.87 \times 10^{-7}$ & $1.40 \times 10^{-9}$ & 1.86 \\
\hline & $1.86 \times 10^{-7}$ & $1.39 \times 10^{-9}$ & 2.07 \\
\hline & $1.84 \times 10^{-7}$ & $1.38 \times 10^{-9}$ & 1.85 \\
\hline
\end{tabular}

\section{CONCLUSION}

This study discusses the wireless V2V charging concept by simulating two line-follower robots acting as the vehicles move side by side, where the vehicle 1 charges vehicle 2 . The maximum transferred voltage is 5.20 volt, and the maximum current is $93.50 \mathrm{~mA}$ with a closed distance of $1 \mathrm{~cm}$. This maximum transferred energy results in the fastest velocity of 210 RPM. The highest distance possible between these two robots are $3.5 \mathrm{~cm}$, and the induction is more robust as the distance is closer. This concept enables charging without the vehicle in a stationary position.

\section{AUTHORS' CONTRIBUTIONS}

All the authors share contributions in this manuscript. T. Dewi and P. Risma designed and directed the project; Y. Oktarina and M. Nawawi performed and supervised the experiments; T. Dewi, and Y. Oktarina conducted data analysis and wrote the article.

\section{ACKNOWLEDGMENTS}

Authors would like to thank Politeknik Negeri Sriwijaya for the support during the accomplishment of this project and manuscript.

\section{REFERENCES}

[1] A. T. Wardhana, A. Taqwa, and T. Dewi, Design of Mini Horizontal Wind Turbine for Low Wind Speed Area, in: Journal of Physics: Conference Series, 2019, Vol. 347, No 1, p. 01202.

[2] R. B. Yuliandi, T. Dewi, and Rusdianasari, Comparison of Blade Dimension Design of a Vertical Wind Turbine Applied in Low Wind Speed, in: E3S Web of Conferences EDP Sciences, 2018, Vol. 68, p. 01001.

[3] T. Dewi, P. Risma, Y. Oktarina, M. T. Roseno, H. M. Yudha, A. S. Handayani, and Y. Wijanarko, A survey on solar cell; The role of solar cell in robotics and robotic application in solar cell industry, in: Proceeding of Forum in Research, Science, and Technology (FIRST), 2016.

[4] H. M. Yudha, T. Dewi, P. Risma, and Y. Oktarina, Life cycle analysis for the feasibility of photovoltaic system application in Indonesia, in IOP Conference Series: Earth and Environmental Science, 2018, Vol. 124, p. 012005.

[5] I. Arissetyadhi, T. Dewi, R. D. Kusumanto, Experimental Study on The Effect of Arches Setting on Semi-Flexible Monocrystalline Solar Panels Kinetik: Game Technology, Information System, Computer Network, Computing, Electronics, and Control. KINETIK, 2020, Vol. 5, No. 2.

[6] T. Dewi, P. Risma, and Y. Oktarina, A Review of Factors Affecting the Efficiency and Output of a PV system Applied in Tropical Climate, in: The IOP Conference Series: Earth and Environmental Science, 2019, Vol. 258, p. 012039.

[7] A. Edward, T. Dewi, and Rusdianasari, The effectiveness of Solar Tracker Use on Solar Panels to The Output of The Generated Electricity Power, in: IOP Conference Series: Earth and Environmental Science, 2019, Vol. 347, No. 1, p. 012130 
[8] BRD. M. Hamdi, T. Dewi, and Rusdianasari, Performance Comparison of $3 \mathrm{Kwp}$ Solar Panels Between Fixed and Sun Tracking in PalembangIndonesia, in: IOP Conference Series: Earth and Environmental Science, 2019, Vol. 347, No. 1, p. 012131

[9] I. N. Zhafarina, T. Dewi, and Rusdianasari, Analysis of Maximum Power Reduction Efficiency of Photovoltaic System at PT. Pertamina (Persero) RU III Plaju, VOLT: Jurnal Ilmiah Pendidikan Teknik Elektro, 2018, Vol. 3, No 1, pp. 19-25.

[10] A. A. Sasmanto, T. Dewi, and Rusdianasari, Eligibility Study on Floating Solar Panel Installation over Brackish Water in Sungsang, South Sumatra, EMITTER International Journal of Engineering Technology, 2020, Vol. 8, No 1.

[11] B. Junianto, T. Dewi, and C. R. Sitompul, Development and Feasibility Analysis of Floating Solar Panel Application in Palembang, South Sumatra, in: Journal of Physics: Conf. Series 3nd Forum in Research, Science, and Technology Palembang, Indonesia, 2020.

[12] F. Setiawan, T. Dewi, and S. Yusi, Sea Salt Deposition Effect on Output and Efficiency Losses of the Photovoltaic System; a case study in Palembang, Indonesia, in: Journal of Physics: Conf., 2019, Vol. 1167, p. 012027.

[13] H. A. Harahap, T. Dewi, and Rusdianasari, Automatic Cooling System for Efficiency and Output Enhancement of a PV System Application in Palembang, Indonesia, in: Journal of Physics: Conf. 2019, Vol. 1167, p. 012027.

[14] H. Budiman, A. Taqwa, RD. Kusumanto, and T. Dewi, Synchronization and Application of IoT for on Grid Hybrid PV-Wind System, in: Proceeding of International Conference on Applied Science and Technology (iCAST) IEEE, 2018, pp. 617-621.

[15] T. Dewi, P. Risma, Y. Oktarina, A. Taqwa, Rusdiansari, and H. Renaldi, Experimental analysis on solar powered mobile robot as the prototype for environmentally friendly automated transportation, in: Journal of Physics: Conference Series, International Conference on Applied Science and Technology (iCAST on Engineering Science) Bali, Indonesia, 2020, Vol. 1450.

[16] Y. Oktarina, T. Dewi, and P. Risma, The Concept of Automatic Transport System Utilizing Weight Sensor, Computer Engineering and Application Journal, 2020, Vol. 9, No. 2, pp. 155-163.

[17] T. Dewi, P. Risma, Y. Oktarina, and A. Taqwa, Wireless Electrical Source for Mobile Application, in: Proceeding of 2017 International Conference on Electrical Engineering and Computer Science (ICECOS), 2017, pp. 338-343.

[18] P. Risma , T. Dewi, Y. Oktarina, and M. T. Roseno, Wireless Energy Transmission System Using Electromagnetic Induction for Home
Appliances, in: Proceeding of 2016 International Electronics Symposium (IES), 2016, pp. 71-75.

[19] P. Risma , T. Dewi, and Y. Oktarina, The Impact of Nodes Distance on Wireless Energy Transfer System Kinetik: Game Technology, Information System, Computer Network, Computing, Electronics, and Control, 2020, Vol. 5, No, 2, pp. 95-102.

[20] S. Chhawchharia, S. K. Sahoo, M. Balamurugan, S. Sukchai, and F. Yanine, Investigation of Wireless Power Transfer Application with a Focus on Renewable Energy, Renewable and Sustainable Energy Review, 2018, Vol. 91, pp. 888-902.

[21] C. Xiao, Y. Liu, D. Cheng, and K. Wei, New Insight of Maximum Transferred Power by Matching Capacitance of a Wireless Power Transfer System, Energies, MDPI, 2018, Vol. 10 No. 688

[22] A. A. Rangelov, H. Suchowski, Y. Silberberg, and N. V. Vitanov, Wireless Adiabatic Power Transfer, Annals of Physics, 201, Vol. 326, pp. 626-633.

[23] R. Torchio, V. Cirimele, P. Alotto, and F. Freschi, Modelling of Road-embedded Transmitting Coils for Wireless Power Transfer, Computers and Electrical Engineering, 2020 , Vol. 88, p. 106850.

[24] M. Goliński, Designing Efficient Wireless Power Transfer Network, Master Thesis in Electrical Engineering, Delft University of Technology, 2015.

[25] M. Kiani and M. Ghovanloo, The circuit theory behind coupled-mode magnetic resonance-based wireless power transmission, IEEE Transactions on Circuits and Systems I: Regular Papers, 2012, Vol. 59, No. 9, pp. 2065-2074.

[26] A. Karalis, M. Joannopoulos, and Soljacic, Efficient Wireless Non-Radiative Mid-Range Energy Transfer, Annals of Physics, 2008, Vol. 323, pp. 34-48.

[27] S. R. Khan, S. K. Pavuluri, and M. P. Y Desmulliez, Accurate Modeling of Coil Inductance for Near-Field Wireless Power Transfer, IEEE Transaction on Microwave Theory and Techniques, 2018, Vol. 66, No. 9, pp. 4158-4159.

[28] A. A. Eteng, S. K. A. Rahim, C. Y. Leow, S. Jayaprakasam, and B. W. Chew, Low Power NearField Magnetic Wireless Energy Transfer Links: A Review of Architecture and Design Approach, Renewable and Sustainable Energy Review, 2017, Vol. 77, pp. 486-505.

[29] M. Rozman, M. Fernando, B. Adebisi, K. M. Rabie, R. Kharel, A. Ikpehai, and H. Gacanin, Combined Conformal Strongly Coupled Magnetic Resonance for Efficient Wireless Power Transfer, Energies, 2016, Vol. 10, No. 498, 18 pages.

[30] D. Liu, H. Hu, and S. Georgakopoulos, Misalignment Sensitivity of Strongly Coupled Wireless Power Transfer System, IEEE Transaction on Power Electronics, 2017, Vol. 3299, No. 7, pp. 5509-5519. 
[31] M. Simic, C. Bil, and V. Vojisavljevic, Investigation in Wireless Power Transmission for UAV Charging in 19th International Conference on Knowledge-Based and Intelligent Information and Engineering Systems, Procedia Computer Science, 2015, pp. 1846-1855.

[32] P. K. Joseph and D. Elangovan, A Review on Renewable Energy Powered Wireless Power Transmission Techniques for Light Electric Vehicle Charging Application, Journal of Energy Storage, 2018, Vol. 16, pp. 145-155.

[33] L. Sun, H. Tang, and S. Zhong, Load-independent output voltage analysis of multiple-receiver wireless power transfer system, IEEE Antennas and Wireless Propagation Letters, 2016, Vol. 15, pp. 1238-1241.

[34] L. Tan, J. Guo, X. Huang, and F. Wen, Output Power Stabilization of Wireless Power Transfer System with Multiple Transmitters IET, Power Electronics, 2016, Vol. 9, No. 7, pp. 1374-1380.

[35] R. Johari, J. V. Krogmeier, and D. J. Love, Analysis and Practical Considerations in Implementing Multiple Transmitters for Wireless Power Transfer via Coupled Magnetic Resonance, IEEE Transactions on Industrial Electronics, 2014, Vol. 61, No 4, pp. 1774-1783.
[36] P. Kong and H. Ku, Efficiency Optimizing Scheme for Wireless Power Transfer System with Two Transmitters, Electronics Letters, 2016, Vol. 52, No. 4, pp. 310-312.

[37] J. Zhang and C. Cheng, Analysis and Optimization of Three Resonators Wireless Power Transfer System for Predetermined Goals Wireless Power Transmission, Energies, 2016, Vol. 9, No. 4, 20 pages. https://doi.org/10.3390/en9040274.

[38] J. Zhang and F. Wang, Efficiency Analysis of Multiple Transmitter Wireless Power Transfer System, Hindawi International Journal of Antennas and Propagation, 2018, Article ID 341523911 pages.

[39] W. Huang and H. Ku, Analysis and Optimization of Wireless Power Transfer Efficiency Considering the Tilt Angle of a Coil, Journal of Electromagnetic Engineering and Science, 2018, Vol. 18, No. 1, pp. 13-19.

[40] S. Syahputra, Y. Oktarina, P. Risma, S. Rasyad, and T. Dewi, Tilt Angle Effect Analysis on Nodes of Inductive Resonance Wireless Power Transfer, in: Proceeding of 2019 International Conference on Electrical Engineering and Computer Science (ICECOS), 2019, pp. 97-101. 